\title{
A língua e a raça: a mestiçagem como uma ideia linguística das letras brasileiras do século XIX
}

\author{
Allice TOLEDO (1) \\ Universidade Federal de Goiás (UFG)
}

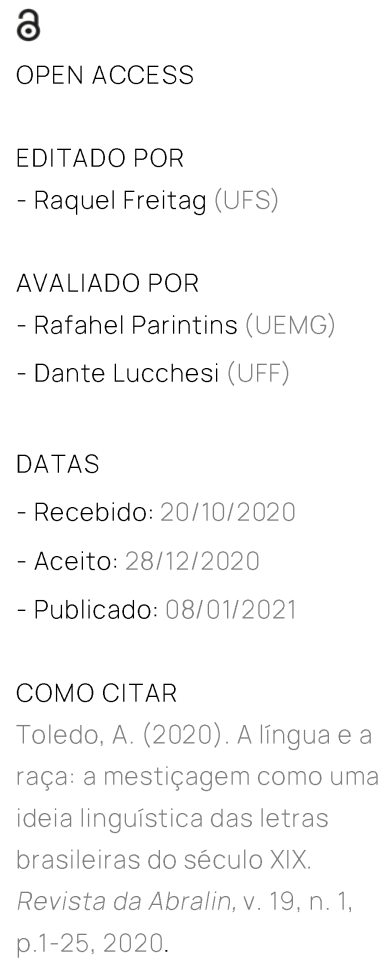

RESUMO

Nosso propósito neste artigo é observar a mestiçagem como uma ideia linguística no século XIX pela análise da produção discursiva das letras brasileiras, aqui entendidas como o conjunto de produções literárias, antropológicas e ensaísticas publicadas no Brasil. A partir do diálogo entre a História das Ideias Linguísticas e a Análise do Discurso a partir do referencial foucaultiano, é nosso intuito demonstrar que havia uma proposta de qualificação da fala e da escrita do português no território brasileiro a partir de critérios raciais. Fundamentamo-nos nos trabalhos que relacionam língua, raça e teorias da linguística, como visto em Trabant (2008), Poliakov (1974), Blikstein (1992) e Rajagopalan (2002). Em seguida, apresentamos a mestiçagem no quadro brasileiro oitocentista a partir de contribuições de Schwarcz (2012) e Alonso (2002). Por fim, pela observação dos pares temáticos mistura e pureza, unidade e diversidade, boa língua e má língua apresentamos as análises de enunciados que tratam de língua e raça, atribuídos a José Bonifácio, Junqueira Freire, José de Alencar, Antonio Henriques Nunes Leal e José Veríssimo. Encerramos com as considerações sobre a mestiçagem como uma ideia linguística recorrente nos enunciados que tratam da língua portuguesa no Brasil e de seus falantes e a contradição como aspecto essencial da produção discursiva sobre essa temática nos anos 1800 .

\section{ABSTRACT}

Our purpose in this article is to observe miscegenation as a linguistic idea in the 19th century by analyzing the discursive production of Brazilian 


\section{REVISTA DA ABRALIN}

letters, here understood as the set of literary, anthropological and essayistic productions. Based on the dialogue between the History of Linguistic Ideas and the Discourse Analysis, regarding Michel Foucault's contribution, it is our intention to demonstrate that there was a proposal to qualify the speech and writing of Portuguese in Brazilian territory based on racial criteria. We are based on works that relate language, race and theories of linguistics as seen in Trabant (2008), Poliakov (1974), Blikstein (1992) and Rajagopalan (2002). Then, we present miscegenation in the 19th century Brazilian framework based on contributions by Schwarcz (2012) and Alonso (2002). Finally, by observing the thematic pairs mixture and purity, unity and diversity, good language and bad language, we present the analysis of statements that deal with language and race, attributed to José Bonifácio, Junqueira Freire, José de Alencar, Antonio Henriques Nunes Leal and José Veríssimo. We end with considerations about miscegenation as a recurring linguistic idea in statements that deal with the Portuguese language in Brazil and its speakers and contradiction as an essential aspect of discursive production on this theme in the 1800s.

\section{PALAVRAS-CHAVE}

Mestiçagem. História das Ideias Linguísticas. Análise do Discurso. Raça. Língua.

\section{KEYWORDS}

Miscegenation. History of Linguistic Ideas. Discourse Analysis. Race. Language.

\section{Introdução}

Este texto foi construído a partir de algumas reflexões derivadas da pesquisa e posterior defesa da tese de doutoramento Os dizeres sobre a mestiçagem nas letras brasileiras entre 1822-1930 (SILVEIRA, 2018), que tratou da descrição e da análise do que se disse acerca da mestiçagem nas letras brasileiras - a produção discursiva literária, linguística e antropológica no Brasil - em meados do século XIX e início do século XX. Pelas análises dos enunciados, demonstramos que a mestiçagem (no sentido apresentado mais adiante) aparece como uma ideia linguística na produção de saberes sobre o português falado no Brasil e uma de suas consequências diretas é preconceito linguístico praticado a partir de critérios étnico-raciais. Embora seja um fato biológico, a ideia de mestiçagem e suas implicações transcendem a fisiologia, atingem o meio social e constituem discursos sobre a língua. Precisamente por isso, ainda que se materialize nas alterações genéticas e fenotípicas dos indivíduos, delimitar um sentido único para as suas consequências na cultura brasileira é muito mais complexo. 


\section{REVISTA DA ABRALIN}

O próprio termo mestiçagem vem sendo amplamente problematizado pelas ciências humanas nas últimas décadas, principalmente em relação aos sentidos homogeneizantes e dominadores em diversos discursos que tratam de questões étnicas no Brasil, como apresentado por Kabengele Munanga (2019), por exemplo. É justamente por este motivo que tal denominação é aqui adotada criticamente, considerando a palavra e seus sentidos em circulação no período em questão e entendendo a mestiçagem não apenas como um fato biológico, mas também como uma ideia linguística. No Brasil oitocentista, era não só um termo que definia a mistura de raças que ultrapassava os limites dos corpos e chegava até a língua, mas uma ideia que também influenciava discussões como a célebre querela da língua portuguesa versus língua brasileira, polêmica que até hoje se estende nas discussões sobre a língua que falamos no país. Naquele momento, esse era um tema de profícuos debates no que chamamos aqui de letras brasileiras, que estabeleciam os parâmetros do bem-falar e do bemescrever da língua portuguesa no Brasil.

Considerando os aspectos incontornáveis que o contato linguístico trouxe ao português europeu, esses homens de letras que compunham a elite intelectual do país, em seus escritos, atribuíam valorações eufóricas ou disfóricas aos modos de falar e de escrever do povo brasileiro a partir de comentários sobre o uso da boa língua ou da má língua nas formulações linguísticas, se era essa a língua pura ou misturada, se essa língua respeitava a unidade ou se dividia-se na diversidade; na maior parte das vezes, esses temas, contemplados aqui em seus pares temáticos (boa língua, má língua; pureza, mistura; unidade, diversidade) relacionavam os aspectos linguísticos aos aspectos raciais, mesmo quando a noção de "raça" não é explicitamente utilizada. Nosso objetivo nesse texto é analisar, por meio do diálogo entre a História das Ideias Linguísticas e da Análise do Discurso a partir do referencial foucaultiano, os enunciados que tratam a mestiçagem como uma ideia linguística do século XIX, usada em defesa ou não da mistura entre línguas ou raças, por meio da observação dos pares temáticos boa língua e má língua, pureza e mistura, unidade e diversidade na produção discursiva das letras brasileiras. É também nosso intuito demonstrar que havia uma proposta de qualificação da fala e da escrita do português no território brasileiro a partir de critérios raciais, mesmo quando categorias raciais não são explicitamente usadas. Nessa conjuntura, os enunciados que conformam as letras brasileiras apresentam uma diversidade de posicionamentos, frequentemente contraditórios, sobre a qualidade e a definição da língua falada no Brasil.

Para tanto, é importante ressaltar algumas questões históricas que legitimam a nossa investigação da mestiçagem como uma ideia linguística no Brasil do século XIX. É sabido que as práticas coloniais e escravocratas da coroa portuguesa garantiram que a mestiçagem se tornasse um caráter distintivo do Brasil em relação a outros países igualmente colonizados (SCHWARCZ, 2012). Foi também tema de grandes obras como Casa grande \& senzala (FREYRE, 2006) e fator de explicação para a constituição da sociedade brasileira, seus motivos de sucesso e de fracasso (cf. SCHWARCZ, 2012; ALONSO, 2002). Como não poderia deixar de ser, o contato racial entre negros, indígenas e brancos também promoveu o inevitável contato linguístico em um país já essencialmente plurilíngue, tendo 


\section{REVISTA DA ABRALIN}

em vista as línguas indígenas ${ }^{1}$ que circulavam no território brasileiro à época da chegada dos portugueses (RODRIGUES, 1993) e as outras centenas de línguas africanas ${ }^{2}$ que vieram forçadamente com os negros escravizados em navios negreiros (PETTER, 2006). Do mesmo modo que o contato racial não foi um fenômeno cujas consequências garantiram uma unanimidade de posições, que em sua grande maioria recusava qualquer tipo de mistura que pudesse alterar a constituição de um povo, assim aconteceu com o contato linguístico. A ideia da pureza racial, presente na sociedade há pelo menos dois mil anos (POLIAKOV, 1974), também se fez presente nas concepções de língua: dessa ideia surgiram diversas políticas linguísticas cujo intuito principal era a garantia da pureza e da unidade da língua em um determinado território. No caso brasileiro, uma das mais célebres políticas de língua foi o Diretório linguístico de Marquês de Pombal em 1757, que visou estabelecer a hegemonia do português por todo o território brasileiro por meio da proibição das línguas gerais (paulista e amazônica) e de quaisquer outros idiomas que não fossem a língua oficial da coroa. Já no século XIX, a mistura de línguas era objeto de observação da intelligentsia brasileira, que por meio dos seus prefácios, posfácios e artigos de jornais tentavam definir qual era, de fato, a língua nacional: o português europeu ou o português do Brasil (FARACO, 2016).

É possível recuperarmos pela descrição dos dizeres sobre a mestiçagem seus diversos significados observáveis nas continuidades e descontinuidades da história brasileira. Nesta diversidade de sentidos, encontramos no horizonte de acontecimentos (FOUCAULT, 2008a, p. 30) uma unidade discursiva: ao longo do século XIX, os sentidos da ideia de mestiçagem nas letras brasileiras podem ser observados a partir dos contornos difusos dos pares temáticos boa língua e má língua, pureza e mistura, unidade e diversidade. A multiplicidade de sentidos de mestiçagem, nestas condições de produção específicas, é um importante indicador das mudanças e, ao mesmo tempo, da permanência do debate sobre o contato racial e o contato linguístico no Brasil, que ultrapassa o limite das questões antropológicas e se manifesta nas tentativas de construção de um saber linguístico no Brasil. Eram os literatos, os doutores das leis, os homens que gozavam de alguma relevância social e política que se incumbiam de refletir e de escrever sobre a cultura e sobre a língua, e toda essa construção de um saber linguístico que trafegava entre o saber oficial e o não oficial estabelecia-se pelo variados gêneros discursivos em que este saber era materializado. Essas produções discursivas circulavam de forma legítima como discursos de autoridade, e essa posição de prestígio que ocupavam é justificada por aspectos históricos incontornáveis para o entendimento da formação de um pensamento científico brasileiro: a ainda incipiente ciência linguística não encontrava espaço nas recém-formadas faculdades brasileiras, de modo que eram os autores literários, os folcloristas e os bacharéis em direito que respondiam à demanda da boa fala e da boa escrita no Brasil.

\footnotetext{
${ }^{1}$ Aryon Rodrigues (1993) afirma que à época do descobrimento, a estimativa teria sido de cerca de 1,2 mil diferentes línguas faladas no atual território pelos povos indígenas.

${ }^{2}$ Sobre as línguas africanas, Margarida Petter (2006) afirma que foram envolvidas pelo tráfico negreiro por volta de 200 a 300 línguas de duas grandes áreas: a área oeste-africana (línguas dos grupos jejê e nagô-queto, como designadas no Brasil) e a área austral, limitada à costa ocidental africana (línguas do grupo banto).
} 


\section{REVISTA DA ABRALIN}

Nas próximas seções, tratamos de algumas das condições de produção que possibilitaram a emergência desses posicionamentos apreciativos ou depreciativos sobre a língua falada no território brasileiro no período oitocentista. E, para cumprir esta tarefa, seguimos a perspectiva da História das Ideias Linguísticas, já que sua proposta consiste em analisar os discursos sobre a produção de saberes linguísticos e não a produção de saberes em si. Em um primeiro momento, trazemos as considerações de Jürgen Trabant (2008), Leon Poliakov (1974), Izidoro Blikstein (1992) e Kanavillil Rajagopalan (2002) sobre as relações existentes entre a teoria linguística e o racismo em diversos momentos da história dos saberes linguísticos. Em seguida, tratamos do quadro brasileiro, especialmente no que concerne à mestiçagem, tanto no contato racial quanto no contato linguístico, e suas consequências para a construção de um saber sobre a língua no período oitocentista, a partir de contribuições de especialistas como Lilia Schwarcz (2012) e Ângela Alonso (2002). Por fim, apresentamos as análises de enunciados que circularam nos anos 1800, proferidos por figuras de relevo para o contexto brasileiro como José Bonifácio, Junqueira Freire, José de Alencar, Antonio Henriques Nunes Leal e José Veríssimo. Encerramos com as considerações sobre a mestiçagem como uma ideia linguística recorrente nos enunciados que tratam da língua portuguesa no Brasil e de seus falantes e a contradição como aspecto essencial da produção discursiva sobre essa temática nos anos 1800.

\section{A teoria linguística e a teoria racial: pontos de intersecção}

As ideias de mistura e pureza, diversidade e unidade, a boa língua e a má língua, que aqui trazemos como pontos privilegiados de observação não são originais da produção de saberes linguísticos no século XIX: são temas presentes nos estudos linguísticos na Europa que remontam aos séculos anteriores, especialmente quando os novos territórios, povos e línguas do além-mar começaram a ser explorados e invadidos pelas navegações europeias. A esse respeito, Jurgen Trabant (2008) sugere que dois eventos importantes na história mundial tiveram influência direta no estabelecimento da linguística como ciência, anterior mesmo às proposições saussurianas: o primeiro evento é a perda da catolicidade do latim e a experiência da diversidade linguística europeia; o segundo é a descoberta das diversas línguas do novo mundo e de outros países distantes. Houve, naquele momento, um ponto de intersecção entre a teoria linguística e a variedade de raças, que se mostrou fundamental para o desenvolvimento do pensamento linguístico moderno. Em ambos os eventos, a herança aristotélica da língua como reflexo do pensamento (TRABANT, 2008) é posta em xeque, e a diversidade torna-se um ponto central da reflexão linguística. Havia um forte embate entre latinistas e vulgaristas à época do primeiro evento, uma vez que as línguas vulgares estavam cada vez mais ocupando espaços antes restritos à língua latina (no curso da justiça, na administração, na ciência e na teologia), espaços estes de erudição e das pessoas do saber. Não por acaso, foi este o momento da 


\section{REVISTA DA ABRALIN}

formação dos Estados nacionais e da ascensão da burguesia na Europa. O status de universalidade da língua latina perdia força frente à reivindicação das identidades linguísticas e, enquanto os vulgaristas separavam língua de pensamento, afirmando a possibilidade de tudo ser dito em todas as línguas, os latinistas insistiam na superioridade estética e cultural do latim, bem como nas qualidades intrínsecas - nesse caso, cognitivas - dos conceitos, que só poderiam ser concebidos e veiculados em língua latina.

Era o início de um movimento com caráter científico de separação e classificação das línguas, uma vez que a unidade linguística atribuída ao latim estava ameaçada, o que, consequentemente, ameaçava as certezas herdadas do período medieval: a de que o latim é a língua universal e a de que o pensamento humano é o mesmo em todos os lugares (TRABANT, 2008). Sendo a diversidade das línguas um perigo, a criação de critérios de categorização entre as línguas (filosóficos, geográficos, genéticos, científicos ou gramaticais), se não combate, ameniza os efeitos da temida diversidade. Jürgen Trabant (2008) destaca quatro modos de reação da "velha Europa" contra essa temida e desconhecida diversidade: a busca por uma unidade entre as línguas a partir de uma única língua de origem (o surgimento da pesquisa histórica das línguas); a demonstração de uma profunda unidade estrutural das línguas (a gramática geral); a luta pela teoria linguística (a partir do princípio aristotélico de negação de diversidade semântica das línguas); a construção de uma nova língua universal ou a reforma daquela já existente (o objetivo da filosofia analítica, especialmente na figura de Francis Bacon).

Estas novas reflexões acerca das línguas adentravam o espectro da cognição, no sentido da relação entre as línguas faladas e a suposta incapacidade racional de determinados povos; pela ciência, seria possível tentar resolver o problema da diversidade das línguas europeias, mas a complexidade trazida pela descoberta do Novo Mundo, suas novas línguas e seus novos povos alterava dramaticamente as experiências de alteridade com as quais o velho mundo precisava lidar. Ainda segundo Trabant (2008), as grandes navegações trouxeram para o conhecimento dos europeus uma variedade nunca vista de povos e línguas, e radicalizou o problema cognitivo que predominava nas reflexões linguísticas de então. Essa radicalização se deu em dois modos: em primeiro lugar, pelas práticas colonialistas de imposição da língua do conquistador aos povos conquistados; em segundo lugar, pela noção de que, de fato, as línguas organizavam-se semanticamente de formas distintas: se esses povos selvagens pensavam diferentemente dos povos europeus, alguma coisa teria a ver com as línguas que falavam. Um ponto incontornável de diferença de pensamento entre os povos era a fé cristã, e o imperativo de levar a esses "selvagens" as palavras de Cristo. Conceitos como "Espírito Santo" ou "Trindade" não eram tão facilmente ensinados como foram antes entre os apóstolos indo-europeus, e as estruturas linguísticas eram entraves à pregação. Foi necessário recorrer à gramatização e dicionarização destas novas línguas, de modo a facilitar a assimilação dos conceitos cristãos europeus. Primeiramente pensada e "resolvida" pelos jesuítas e missionários, essa alteridade torna-se objeto dos chamados filósofos viajantes, o que proporcionou, mais uma vez, o deslocamento de um problema de ordem prática da comunicação para a cognição, para a ciência.

De todo modo, ambos os eventos que Trabant (2008) aponta como fundamentais para a criação de uma ciência linguística alteraram profundamente a forma de teorização em torno da linguagem, e é 


\section{REVISTA DA ABRALIN}

justamente a diversidade linguística a produtora destes novos saberes linguísticos. Nesta perspectiva, era necessário estudar essa diversidade não mais para retornar à unidade, mas para conhecê-la em toda sua extensão e profundidade (TRABANT, 2008). Embora a diversidade tenha ocupado um lugar importante nas reflexões linguísticas, a unidade jamais deixou de ser uma busca por parte da maioria dos estudiosos da linguagem. O projeto da gramática histórica, por exemplo, "é a realização triunfal de uma busca pela unidade no passado, uma busca da identidade no tempo que já tinha três séculos de tradição quando - com Bopp, Grimm e Schlegel - ela encontrou seu método científico", e tornou-se o grande projeto de linguagem do século XIX (TRABANT, 2008, p.123, tradução nossa).

Foram os alemães Franz Bopp, Jacob Grimm e Friedrich Schlegel que estabilizaram em um método a comparação histórica entre as línguas, ofício dos estudiosos da linguagem no século XIX. Foram eles, também, que fortaleceram a hipótese das línguas indo-europeias, até hoje utilizada como critério de categorização e organização das línguas do mundo. Esta hipótese de trabalho desenvolvida no século XIX propunha uma origem comum às línguas europeias e às línguas indo-iranianas. Ao mesmo tempo em que linguistas e filólogos descortinavam a variedade das línguas do mundo, ansiavam por fixar-lhes uma unidade em uma única origem, muitos deles reconstruindo a língua primitiva por meio da comparação. Concernindo a produção pioneira de Friedrich Schlegel (1772-1889), Izidoro Blikstein aponta dois "pontos de honra" defendidos pelo linguista alemão cujos desdobramentos influenciaram os rumos da ciência linguística. O primeiro ponto seria uma aproximação do método de comparação das línguas à perspectiva naturalista-positivista, especialmente quando afirma que a comparação entre as línguas europeias e o sânscrito poderia fornecer "informações inteiramente novas acerca da genealogia da linguagem, assim como a anatomia comparada deitou a luz sobre a história natural" (SCHLEGEL apud BLIKSTEIN, 1992, p. 106). O segundo ponto seria uma supervalorização do sânscrito não a partir de suas especificidades linguísticas, mas sim pela sua remissão às origens mais puras e antigas do povo indoariano. Foi neste ensejo que outras obras fundamentais foram desenvolvidas, como a de Franz Bopp (1791-1867) e a de August Schleicher (1821-1868).

Franz Bopp, considerado o fundador da linguística histórico-comparativa, realizou um estudo de comparação entre o sânscrito e a língua germânica, cuja conclusão apontava para uma similaridade estrutural entre ambas as línguas. Desta similaridade, Bopp concluiu que o alemão, juntamente com o latim e o grego, seria a mais preservada das línguas indo-europeias, pois era aquela que mais se aproximava do sânscrito, reiterando o estreito parentesco entre as duas. Para Blikstein, o apreço de Bopp pela perfeição e pela pureza das línguas indo-europeias levou-o a cometer um "disparate", ao atestar que "as línguas semíticas são de uma natureza menos fina" (1992, p. 107). Disparates à parte, fato é que a pureza era um critério muito significativo no estudo linguístico neste início do século XIX. Tanto era que August Schiller, autor de A língua alemã (1860), ao demonstrar a evolução do indo-europeu para as línguas indo-europeias, declarou que as transformações linguísticas constituíram uma degeneração da origem pura das línguas indo-europeias, e por isso era preciso restituir

\footnotetext{
${ }^{3}$ É importante destacar que os povos judeus nesse contexto também são inferiorizados: foram, juntamente com os povos negros, categorizados na posição mais baixa da hierarquia racial proposta pelos mitos de origem europeus - "Os filhos de Israel estão entre os povos na mesma classe dos negros" (POLIAKOV, 1974, p. XXII.).
} 


\section{REVISTA DA ABRALIN}

o seu tronco, a sua raiz (idem, p. 107). Estas metáforas de caráter naturalista, em que a língua era percebida como um organismo vivo, são um reflexo da concepção linguística hegemônica da época: a língua era como um organismo vivo, que nasce, cresce, envelhece e morre (idem, ibidem). Blikstein sugere uma relação étnica-linguística na elaboração do conceito de arianismo ao apresentar uma lógica entre as explicações sobre a origem do povo e da língua alemães, a saber:

1) O sânscrito, falado pelos aryas, reflete a pureza do indo-europeu;

2) O alemão está próximo do sânscrito e das origens arianas;

3) O alemão também reflete a pureza ariana.

Para Blikstein, resulta daí o "arianismo como um conceito étnico-linguístico", e a concepção de que o alemão é "a língua perfeita de uma raça igualmente perfeita: a raça ariana" (BLIKSTEIN, 1992, p. 108). Rajagopalan (2002) também nos lembra que uma postura similar estava presente na produção de outro linguista alemão, Max Müller, cuja hipótese principal é a de que não podia ser admitida a existência de línguas mistas. Rajagopalan ainda nos diz sobre o impacto de tal hipótese na Alemanha de então, no momento em que a formação de sua identidade nacional estava em franco desenvolvimento: "o que tornava a ideia de línguas mistas algo impensável no imaginário alemão do século XIX era o mesmo que deu origem ao medo da miscigenação, do contato com raças 'inferiores' etc." (2002). Assim como a raça ariana, a língua alemã precisava ser resguardada das influências estrangeiras, da temida diversidade.

No desenvolvimento desta discussão, tocamos aqui em um ponto particularmente sensível às ciências da linguagem. Léon Poliakov atesta que a Linguística já era, em todo o século XIX, uma ciência-piloto para as outras ciências humanas, num momento anterior mesmo à Antropologia Estrutural, "impondo seus métodos e sua autoridade a outras disciplinas humanas" (1974, p. 243). Um exemplo dessa influência é a bipartição entre semitas e arianos, proposta pelos estudiosos da língua alemã e adotada pelos estudiosos de uma nova ciência que surgia por volta de 1860, a antropologia. Embora a assunção dessa interdisciplinaridade não seja uma unanimidade entre os antropólogos, Poliakov faz remissão ao posicionamento de um dos expoentes do positivismo, o antropólogo francês Paul Broca:

\footnotetext{
'os linguistas têm sobre nós uma grande vantagem: é que eles podem viver sem nós, enquanto que nós não podemos viver sem eles (...). Somos, pois, os tributários da Linguística, e tributários reconhecidos; mas não devemos, não podemos ser seus escravos'. À 'teoria ariana', Broca concedia o estatuto de uma probabilidade, não uma certeza: 'Procurando remontar às origens de nossas raças e de nossas línguas, os filólogos, até aqui, encontram probabilidades, não a certeza, e, no estado presente das coisas, temo que os nomes que substituímos ao de indo-europeus não sejam antes a expressão de uma teoria mais do que um fato demonstrado'. (POLIAKOV, 1974, p. 243)
} 


\section{REVISTA DA ABRALIN}

Vemos que Paul Broca aceitava a cientificidade do termo ariano, embora questionasse o caráter de verdade da hipótese das línguas indo-europeias. Nos seus estudos de anatomia e craniologia, Broca desenvolveu o postulado de que as diversidades humanas eram um produto direto das diferenças na estrutura racial, de modo que seu objetivo principal era o de reconstruir "tipos puros" e "raças puras" - arianas -, ao mesmo tempo em que condenava a hibridação humana, sugerindo a possibilidade de que as espécies miscigenadas fossem estéreis (SCHWARCZ, 2015). Nestes limites difusos da interdisciplinaridade entre linguística e antropologia, que se estendem desde o surgimento de ambas as disciplinas, conseguimos recuperar alguns indícios de como a pureza racial e a pureza linguística são conceitos que estão entrelaçados, em maior ou menor grau, em determinadas condições de produção e em determinados períodos históricos. Rajagopalan (2002), sobre o surgimento do nacionalismo alemão, afirma que:

Para Hitler, tanto a língua alemã como a raça alemã precisavam ser urgentemente resgatadas da influência estrangeira. A pureza da língua alemã era o primeiro passo para conseguir a pureza da raça ariana. Contra a "contaminação" que já havia ocorrido devido aos descuidos do passado, só havia um antídoto: limpeza linguística no primeiro caso; limpeza étnica, no segundo. E o slogan do ditador alemão era: "Ein Volk, Ein Reich, Ein Fuhrer". O Terceiro Reich, como argumenta Victor Klemperer (2000), é, antes de tudo, uma linguagem. (idem, s/p)

Defender a língua, o povo e a nação de influências estrangeiras são princípios que começam a ser articulados juntamente a partir do século XIX, uma vez que o imperativo romântico de retomada das origens dos povos interpelava a produção de saber nas mais diferentes esferas. E continuaram a ser articulados juntos no nacionalismo alemão de Adolf Hitler, cujas consequências desastrosas são conhecidas por todos. Evidentemente, os modos de articulação desses princípios não são sempre os mesmos, especialmente porque não seguem as mesmas condições de produção e de emergência. Uma continuidade, entretanto, no que se refere à posição da língua em relação à nação e ao povo, já foi indicada por Carl Darling Buck quando disse que ela é a bandeira mais conspícua de nacionalidade, "para ser defendida contra invasões, como também é o primeiro alvo de ataque por parte de um conquistador que se dedica a destruir o sentimento de nacionalidade dos povos sob o seu domínio". (BUCK, 1916 apud RAJAGOPALAN, 2002).

Quando observamos a produção discursiva de saberes linguísticos no Brasil oitocentista, também vemos o princípio romântico de exaltação e defesa dos patrimônios de uma nação que acabava de nascer. No entanto, eram profundas as contradições sobre quem seria, de fato, o inimigo a ser combatido: o português europeu ou as línguas autóctones que circulavam no território nacional. Em um ambiente em que a mestiçagem era reflexo de um intenso contato racial e linguístico, a mistura das línguas faladas pelo povo brasileiro poderia ser um triunfo ou uma derrota da nação que estava por ser construída, duas visões opostas que encontraram um profícuo espaço nas discussões sobre a língua, temática cara à produção dos intelectuais da época. Como vimos, pureza racial e a pureza linguística são conceitos intrincados em diversos momentos da história das ideias linguísticas na Europa, atuando, inclusive, na construção de saberes e conceitos fundamentais para a história da Linguística. Inevitavelmente, se consideramos o caráter tributarista da produção intelectual brasileira em relação às 


\section{REVISTA DA ABRALIN}

produções de saberes europeias, os temas mistura e pureza, diversidade e unidade, a boa língua e a má língua estão presentes nas elaborações das ideias linguísticas brasileiras. Evidentemente, há diversas particularidades no quadro brasileiro que fazem com que os contornos entre língua e raça sejam mais ou menos difusos. São sobre elas que nos debruçaremos a seguir.

\section{Mestiçagem e língua: o quadro brasileiro}

A concepção de que a língua e a nação são atributos importantes na constituição identitária de um povo já era corrente desde a Revolução Francesa, em 1789, quando o princípio de unificação linguística do povo francês passou necessariamente pela destruição maciça dos patois ${ }^{4}$ dos camponeses franceses e pela obrigatoriedade do ensino de língua francesa em todo o seu território como uma estratégia de fortalecimento do princípio de unidade da nação. O entendimento de que a unidade política de um território nacional "será presumivelmente mais efetiva se for também uma unidade social", como aponta Einar Haugen (2001, p. 105), considera também uma unidade linguística: um único código linguístico realizado em uma única variante. O pretenso ideal de variação mínima na forma "seria uma hipotética variedade 'pura' de uma língua, com apenas uma ortografia e uma pronúncia para cada palavra, uma palavra para cada significado, e uma estrutura gramatical para todos os enunciados" (HAUGEN, 2001, p. 106). Como resultado dessas políticas de unificação, sociedades nacionalistas como a francesa à época da revolução atribuíam a sua identidade coletiva ao ideal de unicidade, e a adoção de uma língua e de uma variante únicas era, mais do que a adoção de uma única língua comum ao povo, uma forma de individuação em relação às demais nações. Ao voltarmos nossa atenção para o caso brasileiro, antes da Revolução Francesa e mesmo antes da independência do país em 1822, já havia uma tentativa ${ }^{5}$ de unificação linguística no Brasil, seguindo o diretório de Marquês de Pombal em 1757. Neste diretório estava atestada a obrigatoriedade da língua portuguesa no território brasileiro e do seu ensino nas escolas, em reprimenda à franca circulação da Língua Geral Paulista e da Língua Geral Amazônica no território brasileiro. Em 1827, cinco anos após a independência do Brasil, foi promulgada uma lei que determinava que os professores ensinariam a ler e escrever de acordo com a gramática "da língua nacional" (DIAS, 1996). Mas qual seria, portanto, essa língua nacional? A língua portuguesa ou a língua brasileira? Ambas foram protagonistas de um acirrado debate, cuja permanência nas discussões da linguística brasileira data até os dias atuais, embora a língua portuguesa assumisse majoritariamente a posição de língua única, frente à

\footnotetext{
${ }^{4}$ Termo usado para designar as línguas locais nas diversas regiões da França, que assume sentidos negativos dentro do contexto da revolução francesa.

${ }^{5}$ Conforme apresentada por Mariani (2004) e Faraco (2016), esta tentativa não se realiza plenamente neste primeiro momento, uma vez que se tratou de uma legislação que em certos momentos enfatizou o ensino do português, em outros o conhecimento da língua geral e ainda em outros momentos propôs conciliar ambos.
} 


\section{REVISTA DA ABRALIN}

possibilidade de o Brasil ser um país plurilíngue. Estabilizado em processos de gramatização e dicionarização, o português europeu permanecia em seu status hegemônico no Brasil entre o século XIX. Já a chamada língua brasileira, frequentemente balizada pelos parâmetros do correto e do incorreto, ou mesmo do feio e do belo, materializava-se principalmente na fala dos brasileiros pela prosódia e pela presença do léxico indígena (e em momentos posteriores o léxico africano). Era também entendida como parte dos projetos literários e ideológicos, por exemplo, nas produções românticas de José de Alencar e de Gonçalves de Magalhães. E nos dizeres sobre a mestiçagem nas letras brasileiras, vemos que todas essas concepções - diversidade, unidade, língua, raça, mistura, pureza, correto, incorreto - têm contornos difusos, ao entrelaçarem-se em enunciados sobre a língua falada e escrita no Brasil; muito frequentemente, o que se diz sobre o mau uso da língua vem associado à mistura linguística dos brasileiros, e esta mistura confunde-se, por vezes, à ideia de uma diversidade linguística, capaz de ameaçar a pretensa unidade da língua nacional.

Em poucas linhas, podemos dizer que a trajetória dos sentidos de mestiçagem na produção discursiva brasileira desdobrou-se da seguinte maneira: durante boa parte do período colonial, a miscigenação entre brancos e indígenas foi percebida pelo princípio rousseauriano de perfectibilidade; sendo iguais por pertencerem à mesma espécie, o que diferenciava os seres humanos de outros seres era justamente a capacidade de "resistir aos ditames da natureza ou acordar neles" (SCHWARCZ, 2012, p. 59); a maldade e outros defeitos de caráter seriam resultado da evolução social, e não da evolução natural. Quando os modelos raciais europeus chegaram ao Brasil na década de 1870, houve uma brusca alteração nesta equação, de tal modo que a evolução social era condicionada pela evolução natural dos seres humanos. Foram estabelecidos critérios de medição da capacidade cognitiva, comportamental e moral dos seres humanos com base na comparação científica das raças - um conceito biológico que havia sido deslocado para as teorias sociais -, atribuindo, assim como aos animais, diferenças básicas entre os seres-humanos. A intelectualidade brasileira à época chegava então à conclusão de que o Brasil era um país antropologicamente singular e inexoravelmente mestiço: "Formamos um país mestiço... somos mestiços se não no sangue ao menos na alma", constatou o crítico literário Silvio Romero (1949) em 1888. Os pensadores estrangeiros, dentre eles o francês Arthur de Gobineau (apud SCHWARCZ, 2012), definiram as peculiaridades da raça brasileira, e nenhuma delas apontava para qualquer forma de progresso econômico e social do país: "Trata-se de uma população mulata, viciada no sangue e no espírito e assustadoramente feia".

O grande destaque desta elite intelectual ao longo do século XIX era a multifuncionalidade: os homens de letras atuavam como políticos, advogados, médicos e simultaneamente dedicavam-se ao trabalho intelectual como biógrafos, historiadores, poetas, jornalistas, romancistas e lexicógrafos. Grande parte deles era vinculada ao Instituto Histórico e Geográfico Brasileiro (IHGB), a mais expressiva instituição de saber do período imperial. Outros foram postumamente escolhidos como patronos da Academia Brasileira de Letras, fundada posteriormente em 1897 por Machado de Assis e seus pares. Todos eles eram originários dos grandes centros urbanos e econômicos do Brasil de então: Rio de Janeiro, São Paulo, Maranhão e Minas Gerais, e a grande maioria realizou sua educação formal em Portugal ou teve acesso à produção acadêmica europeia por meio de viagens. Foram esses os autores que 


\section{REVISTA DA ABRALIN}

produziram a maior parte dos saberes sobre a língua falada no Brasil no período oitocentista, em diferentes gêneros discursivos: cartas, prefácios, posfácios, artigos de opinião, crítica literária.

Para dar conta do nosso intuito de observar a mestiçagem como uma ideia linguística no século XIX, os enunciados aqui apresentados seguiram um critério de seleção estabelecido pela emergência da temática da mestiçagem e das noções a ela relacionadas - mistura e pureza; unidade e diversidade, bom português e mau português - os pares temáticos que direcionam a análise e a interpretação. Demonstramos na seção a seguir os sentidos contraditórios que as palavras mestiçagem, mistura, pureza, unidade e diversidade, por exemplo, assumem nos enunciados que se propuseram a definir, explicar e comentar a língua falada no Brasil em XIX, contribuindo, assim para a circulação da noção de mestiçagem também como uma ideia linguística, além de sua circulação como um conceito relacionado às questões étnico-raciais. O olhar privilegiado aos sentidos contraditórios justifica-se pelo fato de que a contradição é justamente a lei de existência do discurso, e "é a partir dela que ele [o discurso] emerge: é ao mesmo tempo para traduzi-la e superá-la que ele se põe a falar" (FOUCAULT, 2008b, p. 170). Esses enunciados, é importante ressaltar, demandam e legitimam a presença de um autor - que aqui entendemos como elemento agrupador de discursos (FOUCAULT, 2008b), e não como indivíduo dono de um dizer. Seguimos, portanto, com as análises dos enunciados selecionados na dispersão das letras brasileiras do século XIX, tendo como foco privilegiado as relações entre língua, raça e mestiçagem nas suas formulações.

\section{O contato linguístico, o contato racial e a língua falada no Brasil}

A reivindicação de uma individualidade inspirada pela recente independência estava presente na maioria das tentativas de se pensar a nacionalidade pela língua nas letras brasileiras. As posições destes autores indicam o imbróglio que perdurou na história do português falado no Brasil por um longo tempo: a caracterização da língua em língua portuguesa ou língua nacional. Sem a pretensão de definir conceitualmente esta questão fundamental, trazemos a seguir os enunciados atribuídos a autores do período oitocentista que tratam do assunto, cujas tentativas de apresentar explicações para o tema partem de um ponto de vista não só linguístico, mas também racial.

Ode primeira das olímpicas de Píndaro - José Bonifácio (1825)

Para podermos pois traduzir dignamente a Píndaro, ser-nos-ia preciso enriquecer primeiro a língua com muitos vocábulos novos, principalmente compostos, como provavelmente fizeram os mesmos Homero e Píndaro para com a sua: se por fatalidade nossa o imortal Camões, que tanto tirou do latim e do italiano, não ignorasse o grego, certo teria dado ao seu poema maior força e laconismo, e à língua portuguesa maior ênfase e riqueza. Nós já temos muitos vocábulos compostos tirados do latim, e por que não faremos, e adotaremos muitos outros tanto ou mais necessários em poesia, como por exemplo: auricômoda, 


\section{REVISTA DA ABRALIN}

roxicômoda, boquirrubra, bracirrosea, olhinegra, olhiamorosa, argentípede, tranciloira, docirrisonha, docifalante etc. etc. Ousem pois os futuros engenhos brasileiros, agora que se abre nova época no vasto e nascente Império do Brasil à língua portuguesa, dar este nobre exemplo: e fico, que apesar de franzirem o beiço puristas acanhados, chegará o português, já belo e rico agora, a rivalizar em ardimento e concisão com a língua latina, de que traz a origem. (BONIFÁCIO, 1942, p. 110)

Junqueira Freire - Pureza - 1852

Mas hoje Grécia e Roma antiga - o Senhor as apagou do mapa das nações. Já não vivem, já não dominam. Sua civilização ficou incompleta, seu progresso estanque, sua obra infecunda. Mas o fantasma da civilização não para: - como o fluxo e refluxo, se recua, é para avançar com mais força. Assim o orgulho das duas nações dominadoras do globo foi pisado por uma nação conquistada, escravizada. Grécia e Roma foram vencidas pela França. A França abrange o pensamento dos séculos passados, o coração do século presente, a felicidade dos séculos futuros. A França é tudo. Sigamos, pois, a França nas ciências, nas artes, na literatura, assim como a Grécia seguia o Egito, assim como Roma seguia a Grécia, assim como o mundo seguia a Roma, enquanto Roma bastava para o mundo. Sigamo-la, enquanto formos obrigados a seguir exemplos forasteiros. Não contamos senão trinta anos de existência, porque somos brasileiros, não desde que Pedro Álvares Cabral descobriu por acaso as costas do Brasil, mas somente desde que o Brasil gritou nas margens do Ipiranga. - Independência ou morte! (FREIRE, 1869, p. 48 apud PINTO, 1978, p. 24)

\section{José de Alencar - proscrito - 1865}

A língua é a nacionalidade do pensamento como a pátria é a nacionalidade do povo. Da mesma forma que instituições justas e racionais revelam um povo grande e livre, uma língua pura, nobre e rica, anuncia a raça inteligente e ilustrada. (ALENCAR, 1965b, p. 399-400)

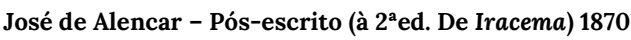

Quando povos de uma raça habitam a mesma região, a independência política só por si forma sua individualidade. Mas se esses povos vivem em continentes distintos, sob climas diferentes, não se rompem unicamente os vínculos políticos, opera-se, também, a separação nas ideias, nos sentimentos, nos costumes, e, portanto, na língua, que é a expressão desses fatos morais e sociais. (ALENCAR, 1965a, p. 169)

Não fazemos senão repetir o que disse e provou um sábio filólogo, N. Webster: - "Logo depois que duas raças de homens de estirpe comum separaram-se e se colocaram em regiões distantes, a linguagem de cada uma começa a divergir por vários modos." - Dic. Ingl. Introdução sobre a origem das línguas. (ALENCAR, 1965a, p. 169)

\section{José de Alencar - Benção paterna - 1872}

Sobretudo compreendam os críticos a missão dos poetas, escritores e artistas, nesse período especial e ambíguo de formação de uma nacionalidade. São estes os operários incumbidos de polir o talhe e as feições da individualidade que se vai esboçando no viver do povo. Palavra que inventa a multidão, inovação que adota o uso, caprichos que surgem no espírito do idiota inspirado; tudo porventura lhe ficaram do chão onde esteve, e apurar o ouro fino. (ALENCAR, s/d, p. 495)

Em uma primeira leitura, os sentidos depreendidos destes enunciados indicam que havia diversas possibilidades de atribuir à língua falada no Brasil a condição de língua nacional. Dentre elas, poderia ser a criação de neologismos, como fizeram Dante e Camões; a inspiração nos modelos franceses de língua e sociedade, em detrimento dos clássicos; ou a assunção de uma língua regional, que fizesse jus às características de seu povo. Independentemente do critério seguido, todas essas 


\section{REVISTA DA ABRALIN}

tentativas de se pensar a nacionalidade pela língua apontam para a reivindicação de uma individualidade inspirada pela recém declarada independência brasileira. Comecemos pela sugestão de José Bonifácio, o "patriarca da independência"6 , de enriquecimento da língua portuguesa por meio da incorporação de neologismos lexicais, especialmente daqueles criados a partir do grego e do latim, os quais garantiriam "mais ênfase e riqueza" ao português. Tal posicionamento não se fundamenta em quaisquer perspectivas científicas, mas em observações pessoais do autor marcadas nos modalizadores discursivos, como em "e fico, (...) chegará o português, já belo e rico agora, a rivalizar em ardimento e concisão com a língua latina, de que traz a origem”. A renovação da língua que sugere Bonifácio é possível graças à abertura de uma "nova época no vasto e nascente Império do Brasil": daí a ousada proposta de neologismos no português a partir de palavras latinas, como "auricômoda, roxicômoda, boquirrubra, bracirrosea, olhinegra, olhiamorosa, argentípede, tranciloira, docirrisonha, docifalante". A predileção pelo clássico nas tradições linguísticas não é uma grande novidade. Lembremo-nos da querela entre os latinistas e os vulgaristas europeus no momento da ascensão do italiano e do francês como línguas nacionais, por exemplo (TRABANT, 2008). No entanto, há aqui uma interessante inversão dos papeis que ocupavam as línguas latina e portuguesa, pela afirmação de que o português "chegará a rivalizar" com o latim, ao menos em ardimento e concisão. O uso do verbo "rivalizar" sugere que há uma posição de igualdade entre ambas as línguas, embora sejam de naturezas distintas, e não uma relação hierárquica entre a língua canônica superior e a língua vulgar inferior. Com as devidas alterações - o amálgama de palavras portuguesas com palavras latinas -, a língua portuguesa e o latim poderiam ser equivalentes nos parâmetros de ardimento e concisão. Inferimos, portanto, que a mistura é benéfica se feita a partir das línguas canônicas, como havia feito Camões, "que tanto tirou do latim e do italiano", o que nos leva a inferir que, deste modo, os parâmetros de pureza linguística permaneceriam inabalados.

Junqueira Freire, poeta baiano da segunda geração romântica no Brasil, apresenta uma proposta de deslocamento do cânone grego e latino para os franceses surge no mesmo horizonte de novas aberturas que citava Bonifácio, proporcionadas pela recém-conquistada soberania brasileira. Se nos atentarmos para o procedimento discursivo da formulação de Freire, temos que é estabelecido um paralelo entre duas nações conquistadas: do mesmo modo que a França superou as nações dominadoras - Grécia e Roma -, o Brasil poderia alçar à condição de civilizado apesar de seu passado de dominação. Sendo a França "tudo", deveria ser também o modelo das ciências, das artes e da literatura do Brasil "enquanto formos obrigados a seguir exemplos forasteiros". Aqui, a conjunção proporcional "enquanto" estabelece, ao mesmo tempo, uma determinação temporal e condicional, de modo que os sentidos desta formulação aludem a uma condição transitória de subalternidade dos brasileiros a mais um modelo forasteiro de civilização. A justificativa de manutenção de uma posição de aprendiz está no fato de que o Brasil, na perspectiva que apresenta Junqueira Freire, só existia há

\footnotetext{
${ }^{6}$ Foi Bonifácio que, quando D. João VI exigiu o retorno de D. Pedro I à corte portuguesa, enviou a carta de exigência para que o príncipe regente permanecesse no Brasil - daí o epíteto de patriarca da independência. Teve seu reconhecimento pelas atuações nas carreiras de estadista, filósofo, advogado e poeta brasileiro, além de ter sido um dos primeiros membros do Instituto Histórico e Geográfico Brasileiro.
} 


\section{REVISTA DA ABRALIN}

trinta anos, já que o marco da existência do país foi a sua independência, e não o seu descobrimento: "somos brasileiros não desde que Pedro Álvares Cabral descobriu por acaso as costas do Brasil, mas somente desde que o Brasil gritou nas margens do Ipiranga - Independência ou morte". Pedro Álvares Cabral é nominalmente o responsável pelo descobrimento, enquanto o responsável pela independência não é D. Pedro I, e sim o Brasil, aqui personificado como substantivo próprio, e não como substantivo pátrio. Se "A França é tudo", o modelo real de civilização, a nação que nos descobriu, não precisa nem ser mencionada. Neste excerto, é possível perceber que Portugal é apenas nomeado quando é feita uma referência explícita à sua ação como algoz, ao "estrangular", "queimar" e "renegar" os primeiros gênios literários genuinamente brasileiros. Mesmo com a emancipação política, não houve a emancipação literária, e "enquanto ela não acontece, e formos obrigados a seguir um norte", era preciso seguir a França, aqui novamente a conjunção reforçando a transitoriedade e a condicionalidade dessa situação.

Do mesmo modo que Portugal não é mencionado nessa busca por novos modelos civilizatórios nas proposições de José Bonifácio e de Junqueira Freire, as nações indígenas que já estavam no território brasileiro anteriormente ao descobrimento e à independência não são mencionadas em nenhum momento. Também não há referência aos povos africanos que vieram logo no início do processo civilizatório e que continuavam a chegar no território brasileiro, ainda que contrariando as proibições internacionais do tráfico negreiro. Havia ainda a força da tradição dos pilares da sociedade ocidental; Grécia, Roma e França permaneciam incontestes em suas posições de damas soberanas da civilização e da cultura mundial. Naquelas circunstâncias, qual outro povo poderia inspirar a pujança de uma nova nação? Eis que o movimento romântico brasileiro insurge com novas respostas a essa pergunta, especialmente com a que consiste em de reconhecer no próprio passado os alicerces da construção de um nacionalismo genuinamente brasileiro. Estavam postas as condições de emergência de outros dizeres sobre o Brasil, o brasileiro e sua língua. Reconhecemos nas falas de José de Alencar um entendimento de língua nacional diferente do de Junqueira Freire e do de José Bonifácio. Pela data de publicação dos textos de que foram extraídos os enunciados do conjunto acima, vemos que são do final da geração anterior àquela da década de 1870, e que a presença do léxico comum à formação discursiva positivista já aparece em razoável quantidade, como "raça" e "progresso". A mestiçagem, portanto, nas produções de José Bonifácio e Junqueira Freire, emerge como uma ideia linguística pautada pelo modo como a mistura linguística e cultural da língua portuguesa com outras línguas europeias se apresenta, ou deveria se apresentar no Brasil; a raça não se apresenta como um fator determinante para essa mistura.

À primeira vista, formulações de José de Alencar, o mais célebre romancista do movimento romântico brasileiro, poderiam causar estranhamento, como em "da mesma forma que instituições justas e racionais revelam um povo grande e livre, uma língua pura, nobre e rica, anuncia a raça inteligente e ilustrada (grifos nossos)". Se houve uma acusação que Alencar enfrentou em toda sua 


\section{REVISTA DA ABRALIN}

vida pública foi a de deturpação da língua portuguesa ${ }^{7}$ ao incorporar em suas obras neologismos e vocábulos de línguas indígenas - pureza linguística, portanto, não era um de seus conhecidos atributos. Outras formulações que também poderiam soar contraditórias a um leitor desavisado são as explicações com metáforas naturalistas de que lança mão para explicar a diferença entre as línguas. Um exemplo disso seria a alusão às variações geográficas e climáticas - "se esses povos vivem em continentes distintos, sob climas diferentes" - são razões também para a separação "nas ideias, nos sentimentos, nos costumes, e, portanto, na língua, que é a expressão desses fatos morais e sociais". Ou ainda a citação direta do filólogo N. Webster, de cunho aparentemente positivista, que exerce nesse excerto a função de argumento de autoridade, a fim de reiterar e validar o raciocínio proposto por Alencar - estratégia ausente nas proposições de Bonifácio e Freire. Cientes do projeto estéticoliterário em que José de Alencar estava inscrito, sabemos que essa proximidade entre língua, homem e natureza, na verdade, é característica do Romantismo, o qual se funda sobre a "correlação entre paisagem e estado de alma" (BOSI, 2013, p. 179). Esta correlação entre homem, língua e paisagem completa um quadro conceitual de nacionalidade entre os românticos, e pode ser observado em trechos como "A língua é a nacionalidade do pensamento como a pátria é a nacionalidade do povo / Da mesma forma que instituições justas e racionais revelam um povo grande e livre, uma língua pura, nobre e rica, anuncia a raça inteligente e ilustrada". As estruturas linguísticas de comparação (é... como/ da mesma forma que ... é/anuncia) colocam em patamar de equivalência a língua, a raça e a nação como formas de expressão do pensamento, da nobreza, da liberdade e da inteligência. Daí a importância de que a ruptura entre Portugal e Brasil não fosse somente política, mas também linguística, uma vez que "não se rompem unicamente os vínculos políticos, opera-se, também, a separação nas ideias, nos sentimentos, nos costumes, e, portanto, na língua, que é a expressão desses fatos morais e sociais.". A condução da argumentação de Alencar a favor da separação linguística entre os dois países segue uma lógica causal, marcada pela conjunção "portanto" ao apresentar a conclusão final de seu raciocínio que se funda nas premissas de que a língua é a expressão das ideias, dos sentimentos e dos costumes de um povo.

Também caro ao Romantismo, é visível o princípio rousseariano de perfectibilidade nas proposições alencarianas, em que a concepção de homem - povo - não se divide em raças, no plural, mas em apenas uma raça: embora diversos, todos os homens pertencem a um mesmo gênero. E a língua é a expressão máxima da nacionalidade coletiva deste povo - é, de fato, o seu pensamento. Seriam os escritores e os poetas os responsáveis por "polir o talhe" dessa língua, e dar-lhe os caracteres de pureza, nobreza e riqueza que a ela seriam necessários. Não está evidente nestes enunciados, mas em tantos espalhados na dispersão é possível identificar a reivindicação de Alencar pela individualidade da língua brasileira, e esta passa incontestavelmente pelo reconhecimento da herança indígena e de sua influência na cultura e no falar brasileiro. Vale ressaltar que os sentidos de mistura linguística nestas condições diferem-se de acordo com as diferentes línguas que são postas em relação:

\footnotetext{
${ }^{7}$ Todas essas contendas, inclusive, fazem parte do que Eduardo Guimarães (1996) chama de discurso polêmico, além de serem matéria principal de Alencar e a língua brasileira, de Gladstone Chaves de Melo (1972).
} 


\section{REVISTA DA ABRALIN}

neologismos derivados do latim clássico, como sugeriu José Bonifácio, por exemplo, enriquecem a língua; o caso não é o mesmo com outras línguas de origem menos nobre. O mesmo conceito, portanto, pode comportar sentidos opostos especialmente quando se referem à língua: há a pureza boa e pureza ruim, assim como há a mistura boa e mistura ruim.

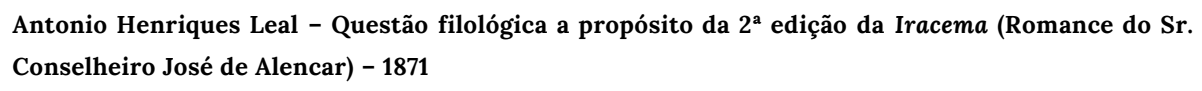

Sem dúvida, as propostas de José de Alencar foram foco de inúmeras polêmicas entre a comunidade intelectual brasileira da época. Para Antonio Henriques Leal, médico, escritor e membro do IHGB, José de Alencar é o autor da "falsa doutrina" que visa tornar independente a língua da nação brasileira. Frente a essa possibilidade de diversidade linguística, sobressaem os adjetivos disfóricos como "falsa", "perigosa", "intolerável", "menos expressiva", "sem elegância" para denominar este novo "idioma nacional", capaz de produzir "algaravia bárbara" e "ininteligível". Todas essas considerações passaram pelo crivo de um julgamento de valor, uma vez que esses adjetivos pertencem ao campo semântico correspondente à modalidade apreciativa. O que, nestes enunciados, possivelmente se aproximaria mais de uma explicação científica contrária à ideia de idioma nacional seria o paralelo feito entre língua e pensamento: a adoção de um modo de dizer "impróprio e bárbaro" que não obedecesse às "boas regras" poderia levar a uma "confusão no modo de exprimir as ideias". Por inferência, podemos dizer que a concepção de língua como expressão do pensamento humano justifica a necessidade de que, para se manter uma boa sociedade, que obedece às boas regras, era necessário que se mantivesse a boa língua, isenta de impropriedades e barbarismos - como é o caso dos neologismos. Há também, nos dizeres de Leal, o uso de uma metáfora como um recurso para personificar tanto a língua quanto os elementos 


\title{
REVISTA DA ABRALIN
}

estrangeiros ao português brasileiro: estes são "parasitas" que a enfraquecem e a disformam, esgotamlhe a "seiva da vida" e eventualmente poderão torná-la um "cadáver".

Não é preciso que a palavra "neologismo" esteja citada na materialidade linguística da metáfora para que o sentido de "parasitas" possa ser atribuído às outras línguas que não a portuguesa, inclusive ao léxico das línguas nativas e africanas. Pelos adjetivos "bárbaro" e "forasteiro", por exemplo, é possível a remissão ao já-dito sobre essas línguas, inclusive aos adjetivos que comumente eram empregados para classificá-las, como bárbaro e peregrino. De todo modo, é possível destacar que essa personificação da língua como um organismo vivo era comum naquele momento ${ }^{8}$, e que indica uma forte presença do discurso naturalista nas ideias linguísticas. Esta é mais uma evidência de que, nas continuidades e descontinuidades da história, não se pode fixar um ponto de origem ou de encerramento dos discursos; a ordem do discurso (FOUCAULT, 2008b) de cada tempo se encarrega de permitir a ausência ou a presença de movimentos de pensamento tão contraditórios em uma mesma formação discursiva - a aqui reconhecida como letras brasileiras.

Nos trechos a seguir da obra Linguagem, escrita pelo crítico literário José Veríssimo, há menos a presença de uma modalidade apreciativa, que explicita juízos de valor sobre o uso e o funcionamento da língua, e mais a presença de um olhar científico sobre as ocorrências de língua no Brasil:

\begin{abstract}
José Veríssimo - Linguagem - 1886
De quantos elementos étnicos tem concorrido para a formação da nossa nacionalidade, o que mais influiu para a adulteração do português na América foi sem dúvida indígena, representado pela família que fala o tupi-guarani. Atualmente não só nomes de geografia brasileira, da nossa flora e fauna, de certos utensílios de selvagens com que nos servimos (o tipiti, a cuiambuca, a gurupema etc.) mas um grande número de palavras indígenas corrompidas (caipira, moquear, tijuco etc.) ganharam direito de cidade em um vocabulário português, porque, como bem diz o Sr. Batista Caetano d'Almeida Nogueira "a língua tupi, apesar de ser língua de bárbaros, uns exterminados, outros corridos pelos matos, outros em fim escravizados, fundidos, amalgamados com os conquistadores, inoculou nas línguas vencedoras e civilização não somente vocábulos e termos que figuram até hoje nos livros de ciência, mas ainda fraseados, idiotismos e cacoetes. A supressão de uma ou mais letras no final das palavras, tão usual entre os brasileiros, principalmente entre os caboclos e caipiras, é um cacoete herdado dos índios e desconhecido aos portugueses que, pelo contrário, procuram tornar brevíssimas as sílabas não acentuadas do meio ou do princípio das palavras. (VERÍSSIMO, 1886, n. p. apud PINTO, 1976, p. 246)

O filho de uma de nossas capitais, onde o elemento verdadeiramente brasileiro tenha sido sufocado pelo estrangeiro, do Rio de Janeiro ou Pernambuco, por exemplo, subitamente transportado para as margens do Amazonas ou de seus afluentes, para as regiões da seringa ou castanha na época dos ajuntamentos periódicos, ficaria certamente surpreso de ouvir uma língua, que reconheceria portuguesa, é verdade, mas na qual o modo de dizer, inúmeros termos, a mesma construção é toda estranha, e saindo de lá notaria que em todos os lugares das duas províncias o fato se reproduz apenas com diferença de intensidade. (VERÍSSIMO, 1886, n. p. apud PINTO, 1976, p. 247)
\end{abstract}

\footnotetext{
${ }^{8} \mathrm{O}$ primeiro capítulo da tese Os dizeres sobre a mestiçagem nas letras brasileiras entre 1822-1930 (SILVEIRA, 2018), é dedicado às análises dos enunciados que tratam de língua, raça e mestiçagem no século XIX atribuídos não somente aos autores mencionados neste artigo, mas também de outros importantes intelectuais com Vaarnhagen, Gonçalves Dias e Gonçalves de Magalhães. Um dos resultados mais relevantes da análise foi observar como eram frequentes as relações estabelecidas entre língua e natureza nos enunciados acerca da língua falada no Brasil.
} 


\title{
REVISTA DA ABRALIN
}

\begin{abstract}
Nem é difícil compreender e explicar como tal fato se deu. O índio começou por traduzir verbum ad verbum a sua frase para o português, e assim construiu esta como aquela, exceto quando não se achava na língua portuguesa, por desconhecê-las, expressões que traduzissem perfeitamente o seu pensamento, como se deu com o será, que sendo o interrogativo tupi, não podia ser traduzido senão pelo sinal ortográfico, que ele desconhecia, razão por que conservou aquele na frase portuguesa. O mesmo aconteceu com o artigo, que por o não terem na sua língua, deixaram de traduzir, dizendo a sua frase portuguesa como diziam a tupi. (VERíSSIMO, 1886, n. p. apud PINTO, 1976, p. 249)
\end{abstract}

Nas variações fonéticas da língua vê-se ainda a influência aprontada. O desaparecimento do $r$ forte no final dos verbos, como em morrê, levá, ganhá, pô, fugi por morrer, ganhar, levar, pôr, fugir, não se explica senão pela falta daquela letra no alfabeto indígena, ou melhor, daquele som na sua língua. (VERíSSIMO, 1886, n. p. apud PINTO, 1976, p. 249)

O autor faz suas considerações colocando em questão os fatores étnicos e culturais que incidiram na formação da nacionalidade e nas alterações linguísticas observadas no território brasileiro. Em suma, José Veríssimo examina a herança indígena na língua falada, dando grande destaque às diferenças regionais que incorrem nas alterações da prosódia e da sintaxe. Certamente, Veríssimo não é o primeiro observador das diferenças regionais, mas suas anotações demonstram uma preocupação em descrever as estratégias de aquisição de língua dos indígenas para explicar o modo como ocorrem as peculiaridades no português popular do Brasil. Nada disso é feito, no entanto, sem antes as relações de superioridade e inferioridade das raças serem postas em questão. Pela citação literal de Batista Caetano d'Almeida Nogueira, introduzida como um argumento de autoridade, José Veríssimo refere-se à língua tupi segundo a lógica da hierarquia linguística, atribuindo-lhe uma posição de inferioridade, já que era uma língua de "bárbaros, uns exterminados, outros corridos pelos matos, outros em fim escravizados". Apesar desta sua condição de menor valor, estes povos "fundidos, amalgamados com os conquistadores" - misturados, portanto, - incutiram palavras de suas línguas nas línguas vencedoras e civilizadas. Aqui é importante a atenção ao uso do verbo "inocular", majoritariamente presente no campo semântico da biologia, referente a ação de um predador que insere seu veneno em uma presa. Há um reforço dessa ideia quando Veríssimo afirma serem as etnias tupiguarani as principais responsáveis pela "adulteração" do português, disseminando suas "palavras indígenas corrompidas" não somente para referência de nomes da geografia, da flora e da fauna brasileira, ou de "certos utensílios de selvagens com que nos servimos", mas também "fraseados, idiotismos e cacoetes". Todas as referências às línguas da família tupi-guarani valem-se de termos disfóricos: "adulteração", "palavras indígenas corrompidas", "bárbaros", "selvagens", "idiotismos", "cacoetes". Nesta relação sugerida por Veríssimo entre o conquistador e o conquistado, entende-se por analogia que assim como uma presa inocula o veneno em seu predador no momento da sua morte, o mesmo fez a língua tupi com a língua portuguesa no Brasil, que se tornou repleta de termos que lhes são estranhos à sua essência original - sua pureza, portanto, havia sido maculada pela mistura.

Seguindo essa linha argumentativa, José Veríssimo observa e estabelece diferenças evidentes entre o modo de falar daqueles que habitam as capitais e aqueles que vivem no interior do Brasil. Supondo que um "filho da capital" se deslocasse até o Amazonas e seus afluentes, Veríssimo afirma que a reação seria de surpresa ao "ouvir uma língua, que reconheceria portuguesa, é verdade, mas na qual o modo de dizer, inúmeros termos, a mesma construção é toda estranha". Acrescenta ainda 


\section{REVISTA DA ABRALIN}

que "em todos os lugares das duas províncias o fato se reproduz apenas com diferença de intensidade." Essa observação pode ser lida como um esboço do que a sociolinguística, muitos anos depois, elegeria como um dos seus focos de análise: a variedade linguística. No exemplo trazido por Veríssimo, vemos que além de fazer uma distinção regional entre o falar da capital e o falar do interior, faz também uma distinção entre o falar dos portugueses e dos "caboclos" e "caipiras" a partir da análise de caráter fonológico, evidentemente sem o rigor da disciplina que só seria constituída anos depois: "a supressão de uma ou mais letras no final das palavras, tão usual entre os brasileiros, principalmente entre os caboclos e caipiras, é um cacoete herdado dos índios e desconhecido aos portugueses". Importante lembrar que o nome "caboclo" faz referência àqueles que são frutos do cruzamento entre a raça branca e a raça indígena, e que os "caipiras" são aqueles também frutos do cruzamento das raças branca, indígena e negra, e que habitam no interior do Brasil. Eram os mestiços, portanto, que realizavam tais formas linguísticas em sua fala, o que garante um caráter racial à análise da língua proposta por Veríssimo.

Ainda nesse escopo, destacamos a breve consideração feita pelo autor sobre o processo de aquisição de segunda língua por parte dos indígenas brasileiros, que teria influência direta nas mudanças do português originário da Europa: "O índio começou por traduzir verbum ad verbum a sua frase para o português, e assim construiu esta como aquela, exceto quando não se achava na língua portuguesa, por desconhecê-las, expressões que traduzissem perfeitamente o seu pensamento". Neste dizer, temos dois pontos importantes pelo que tematizam e pelo modo como são formulados: a aproximação de uma abordagem metalinguística sobre a língua falada no Brasil; a concepção de língua vigente que justificava a possibilidade de tradução de pensamento por meio da linguagem, o que garantia a diferenciação entre o falar dos brancos e dos mestiços a partir de uma caracterização racial. Em relação ao primeiro ponto, o afastamento de uma modalidade apreciativa sobre o tratamento das línguas indica um movimento de cientificização do saber linguístico, já que as características imanentes às línguas em questão (a supressão de fonemas do português, o acréscimo de fonemas de línguas indígenas) sobrepunham a avaliação eufórica ou disfórica, tão comum em outros enunciados em circulação naquele mesmo período. O segundo ponto de destaque é a concepção de língua que José Veríssimo adota para pautar suas discussões - a mesma vigente à época, a língua como expressão do pensamento. Falantes de línguas e de raças diferentes pensavam de modo diferente, e essa seria a razão pela qual indígenas, caboclos, caipiras e portugueses produziam a língua de modos distintos. Veríssimo sugere que o modo como os indígenas fizeram a tradução do tupi para o português, verbum ad verbum (palavra por palavra), não foi eficiente para "expressassem perfeitamente o seu pensamento", já que não havia equivalentes para suas expressões próprias. Veríssimo cita o exemplo do artigo, "que por o não terem na sua língua, deixaram de traduzir, dizendo a sua frase portuguesa como diziam a tupi". Cita também as variações fonéticas da língua, com o "desaparecimento do $r$ forte no final dos verbos, como em morrê, levá, ganhá, pô, fugi por morrer, ganhar, levar, pôr, fugir", cuja explicação residia na "falta daquela letra no alfabeto indígena, ou melhor, daquele som na sua língua". Como um prenúncio do que Amadeu Amaral faria anos mais tardes, a explicação do "'r' caipira" também figurou em suas análises, como vemos no trecho que segue: 


\title{
REVISTA DA ABRALIN
}

\begin{abstract}
A substituição do $l$, cujo som também não tinham, pelo $r$ brando, que possuíam, nas palavras que em português trazem aquela línguo-palatal com o som bem caracterizado, como em malvado, alqueire, alcançar, que eles dizem marvado, arqueire, arcançar, como também a perda do $l$ no final das palavras $f e l$, mel, qual etc., que pronunciam fé, mé, quá, não tem, parece-me, outra causa. Outras vezes em lugar do $l$ final põem o $r$ brando, como em animal, que dizem animar. Tenho ouvido pronunciar Escola Normar a professores dali saídos. Não dão jamais o sinal de plural aos substantivos, e assim dizem as casa, os peixe; Amazona, em vez de Amazonas. (VERÍSSIMO, 1886, n. p. apud PINTO, 1976, p. 249)
\end{abstract}

Nota-se também na sua pronúncia de algumas vogais uma diferença bastante sensível da dos outros mestiços do Brasil. O é, que tem em outras províncias, como Pernambuco, Bahia e Rio de Janeiro, o som de $i$, como em di por de, aqui é aberto, embora não tanto com em S. Paulo. O o fechado pronunciase $u$. Daí veio a sátira que nos fazem os filhos do Sul, de que nós dizemos: Lá vem uma canua carregada de cuco de pupa a prua. Com efeito, é assim paraenses e amazonenses pronunciam aquela frase, mas a esse respeito seja-me permitido dizer que, quanto a este ponto, os filhos do Sul não têm muita razão, pois que julgo mais lícito em português, mais conforme com a fonética da língua, transformar o o fechado em $u$, do que em o aberto, como lá fazem, dizendo bótá (r), córóa, corrê (r). Em Portugal pronunciam-se estas palavras com o o perfeitamente fechado, como no Amazonas. Em regra geral pode-se dizer que no sul há tendência para abrir vogais fechadas, dá-se aqui o contrário, pronunciam-se como fechadas aquelas que têm sons abertos, ou pelo menos fecham-se mais os sons. (VERísSIMO, 1886, n. p. apud PINTO, 1976, p. 250)

Esta influência da língua falada pela raça vencida e inferior que, como acabamos de ver, foi tão grande sobre a sintaxe e a lexicologia da língua conquistadora e superior, ressalta com maior evidência quando se estuda os vocábulos por ela introduzidos nesta. Na linguagem popular das províncias amazônicas tais vocábulos são em crescido número, e a seguinte lista deles, embora incompleta e deficiente, é, todavia, bastante para provar a ação do tupi sobre o português nesta vastíssima zona, e em todo o Brasil, pois que muitas dessas palavras são também vulgares na língua popular de muitas outras províncias. (VERÍSSIMO, 1886, n. p. apud PINTO, 1976, p. 251)

Estava presente a noção de que "os mestiços do Brasil" realizavam a pronúncia das palavras portuguesas de modo distinto entre si - considerando as diferenças regionais -, e em relação aos falantes da pátria-mãe. A indicação da condição racial destes falantes, reforçada pelo uso do termo "mestiço", não deixa de reiterar a influência da língua da "raça vencida e inferior", que foi "tão grande sobre a sintaxe e a lexicologia da língua conquistadora e superior". Sem dúvida, esses dois tipos de contato - o racial e o linguístico - não poderiam ser dissociados, pois se a expressão do pensamento de um povo era demonstrada na sua produção de língua, o pensamento dos "mestiços do Brasil" expressos pela mistura de pronúncias e vocábulos na "língua popular" refletia a mistura racial a que foram submetidos pela colonização e, consequentemente, demonstrava a mistura linguística na fala. Não havia espaço, portanto, para a unidade na modalidade oral da língua, mas na modalidade escrita permanecia intacta graças ao trabalho de defesa dos escritores, capazes de revestir a língua de proteções contra as "invasões descabidas da língua popular". Se existe a possibilidade de resumir as ideias apresentadas por José Veríssimo segundo os parâmetros de análise que nós estabelecemos, podemos dizer que, simultaneamente, a noção de mistura assume sentidos eufóricos e disfóricos quando se pensa na divisão da língua oral e escrita: é eufórica quando garante a autenticidade de uma língua "nova, e não diversa", típica da nação soberana brasileira; é disfórica quando ameaça a integridade da língua portuguesa escrita e da literatura nacional, ao ponto da necessidade de defendê-las das invasões bárbaras da língua tupi, a língua inferior dos conquistados. 


\section{REVISTA DA ABRALIN}

\section{Considerações finais}

É certo que a relação entre língua e raça não configura uma novidade no âmbito dos estudos sobre linguagem, história e sociedade. Entretanto, ao suspendermos as unidades já formadas nestes campos de saber (FOUCAULT, 2008a), foi possível encontrar novos recortes e novas unidades que nos auxiliaram na descrição dos acontecimentos discursivos em determinados momentos da história, especialmente naqueles em que o contato linguístico e o contato racial eram postos em relevo. A ordem do discurso de cada período histórico conjura os "poderes e perigos" (FOUCAULT, 2008b) dos dizeres. Se nos predispomos a trabalhar com a descrição de saberes linguísticos, sabemos que isso se demonstra pelos inúmeros contrapontos e contradições nos enunciados que formam o domínio das letras brasileiras. Nessa conjuntura, a contradição, além de esperada, é o que faz movimentar a produção discursiva do que convencionamos aqui chamar de letras brasileiras, em que o tema da mestiçagem aparece pelo entrecruzamento de língua e raça na construção de uma ideia linguística, ainda que a ideia de "raça" não esteja sempre explícita. É o que podemos observar nos posicionamentos de José Bonifácio, Junqueira Freire, José de Alencar, Antonio Henriques Leal e José Veríssimo: embora contemporâneos, suas produções discursivas são contraditórias entre si e, em alguns casos, contraditórias em si mesmas. Nesta perspectiva, materializados em enunciados que circulam no domínio das letras brasileiras, os dizeres sobre a mestiçagem refletem e refratam a estigmatização ou o prestígio dos falantes de acordo com certas contingências discursivas. O mesmo acontece quando os pares temáticos boa língua e má língua, pureza e mistura, unidade e diversidade são observados nas análises dos dizeres que tratam da língua falada no Brasil.

Um exemplo de como a contradição é um aspecto essencial da produção discursiva das letras brasileiras é o modo como o contato linguístico do português com outras línguas é abordado pelos homens de letras. Quando observamos o par temático mistura e pureza, vemos nas propostas de José Bonifácio que a mistura entre o latim e o português pela inserção de neologismos derivados do latim clássico como "auricômoda" seria uma estratégia para enriquecer o português. Já nos enunciados atribuídos a José Veríssimo, o sentido eufórico do tema da mistura não é correspondente aos enunciados de Bonifácio, já que Veríssimo afirma que as "palavras indígenas corrompidas" são as responsáveis pela "adulteração" do português no Brasil. Ou então quando Antonio Henrique Leal, ao tratar do português do Brasil misturado com as línguas indígenas, alerta sobre a importância do estudo dos clássicos que devem servir para "desarraigar dela tantas parasitas que a vão enfraquecendo, disformando e esgotando-lhe a seiva da vida, de modo a torná-la ainda um dia cadáver." Quando a proposta de combinar o português com o latim é apresentada, é evidente o caráter eufórico que a mistura assume, já que o latim, sendo uma língua superior, é capaz de engrandecer a língua da nova nação que se formava após a independência. Já quando as evidências do contato entre as línguas indígenas e a língua portuguesa são demonstradas, o caráter disfórico de mistura é predominante, posto que a presença do léxico de línguas "bárbaras" seria uma forma de corromper o português original, sendo necessário extirpar essas influências antes que essa mistura possa culminar na morte da língua portuguesa. É possível estabelecer uma relação de identidade entre essas proposições e as de Max 


\section{REVISTA DA ABRALIN}

Müller (apud RAJAGOPALAN, 2002) acerca da presença de línguas mistas no território nacional alemão, quando disse serem as línguas mistas tão nocivas à nação alemã quanto a mistura da raça branca com as raças consideradas inferiores. Naquele momento histórico, resguardadas todas as diferenças sócio-históricas e culturais entre Brasil e a Alemanha, a mistura, consequência da diversidade étnica, era um temor comum às duas nações.

Ainda no tema da diversidade e da unidade, as contradições na produção discursiva das letras brasileiras também podem ser constatadas quando buscamos as proposições de José de Alencar e Antonio Henriques Leal, diametralmente opostas sobre a língua da nação brasileira. Alencar propõe que, para pensar a independência política, a separação dos vínculos políticos é tão necessária quanto a "separação da língua para a formação da individualidade de uma nação". Declaradamente contrário ao seu posicionamento, Antonio Henriques Leal, ao abordar a proposta de diversidade linguística, classifica como "falsa", "perigosa", "intolerável", "menos expressiva", "sem elegância" a ideia de um novo idioma nacional. Embora a diferença que os sentidos de diversidade assumem na produção de cada um dos autores, é incontornável reconhecer a identidade entre essa contenda e o conflito entre os latinistas e os vulgaristas europeus no momento da ascensão do italiano e do francês como línguas nacionais (TRABANT, 2008). Embora com séculos de diferença, essas altercações mostram a permanência de certos sentidos de pureza atribuídos à ideia de unidade linguística, assim como a noção de que a diversidade linguística oferece ameaça ao cânone.

Se retomarmos as condições de produção dos enunciados aqui analisados, é necessário lembrar que a gramatização (AUROUX, 2008), a dicionarização e o acesso ao letramento eram primordialmente feitos pela elite e destinado à elite, majoritariamente urbana neste período e que, escusado dizer, era composta por brancos e mestiços cuja coloração da tez pendia para o branco. Como eram a literatura e a ciência campos de saber hegemonicamente constituídos e direcionados àqueles com acesso à educação formal, foram os escritores, os advogados e os demais homens que compunham a elite intelectual oitocentista importantes agentes na implantação da norma padrão do português, seguindo um projeto político de nação sob as diretrizes da elite brasileira (PAGOTTO, 1998). Por essa razão, as noções de boa língua e de má língua eram frequentemente abordadas na produção discursiva das letras brasileiras com vistas a estabelecer parâmetros de avaliação da língua portuguesa falada e escrita pelos brasileiros, especialmente pelos mestiços, pelo povo. Naquele período, segundo José Veríssimo, eram os mestiços, falantes da "linguagem popular", que difundiam a má língua, diretamente influenciada pelas línguas de "raças inferiores", como era o caso das línguas do tronco tupi. Em momentos posteriores, especialmente após a abolição da escravidão e o reconhecimento dos negros como cidadãos brasileiros, as línguas africanas também foram responsabilizadas pela intelligentsia brasileira do fim do século XIX e início do século XX como influência negativa para o português do Brasil (SILVEIRA, 2018). Pelas continuidades e descontinuidades da história (FOUCAULT, 2009a), hoje, o que a prescrição gramatical entende como o mau português é falado pelas classes mais baixas, com parco acesso à educação formal, sem grandes oportunidades de ascensão social, como analisam sistematicamente Dante Lucchesi (2015), Marcos Bagno (1999; 2003) e Carlos Faraco (2008; 2016). Uma das principais contribuições deste trabalho, que trata da mestiçagem no quadro 


\section{REVISTA DA ABRALIN}

brasileiro oitocentista, é a de conceber, de um ponto de vista discursivo e histórico, que a relação entre o mau português e os falares das classes mais baixas possui uma motivação étnico-racial importante. No Brasil, vale lembrar, a pobreza tem cor, e há séculos o preconceito linguístico tem o mesmo alvo: são, como diria Caetano Veloso (1993), os “quase brancos", os "quase pretos", os "quase brancos pobres como pretos", que são "quase todos pretos".

\section{REFERÊNCIAS}

ALENCAR, José de. Iracema. Edição do Centenário. Rio de Janeiro: José Olympio, 1965.

ALENCAR, José de. Obra completa. Rio de Janeiro: Aguilar, 1960, vol. IV.

ALONSO, Angela. Ideias em movimento: a geração. 1870 na crise do Brasil Império. São Paulo: Paz e Terra, 2002.

AUROUX, Sylvain. Questão da origem das línguas. A historicidade das ciências. Campinas: RG, 2008.

BAGNO, Marcos. Preconceito linguístico: o que é, como se faz. São Paulo: Parábola Editorial, 1999.

BAGNO, Marcos. A norma oculta: língua e poder na sociedade brasileira. São Paulo: Parábola Editorial, 2003.

BLIKSTEIN, Izidoro. Indo-europeu, linguística e racismo. Revista USP, v. 14, p. 104-110, 1992.

BONIFÁCIO, José. Poesias de Américo Elísio. Rio de Janeiro: Academia Brasileira de Letras, 1942.

BOSI, Alfredo. História concisa da literatura brasileira. São Paulo: Cultrix, 2006.

BOSI, Alfredo. Cultura. In: SCHWARCZ, Lilia Moritz (dir.). História do Brasil Nação: 1808-2010. Volume 2: A construção nacional, 1830-1889. Rio de Janeiro: Objetiva; Madrid: Fundación MAPFRE, 2013.

DIAS, Luis Francisco. Os sentidos do idioma nacional: as bases enunciativas do nacionalismo linguístico no Brasil. Campinas: Pontes, 1996.

FARACO, Carlos. Norma culta brasileira: desatando alguns nós. São Paulo: Parábola Editorial, 2008.

FARACO, Carlos. História sócio-política da língua portuguesa. São Paulo: Parábola Editorial, 2016

FOUCAULT, Michel. A arqueologia do saber. Rio de Janeiro: Forense Universitária, 2008a

FOUCAULT, Michel. A ordem do discurso. São Paulo: Edições Loyola, 2008b.

FREIRE, Junqueira. Elementos de retórica nacional. Rio de Janeiro: Laemmert, 1869.

FREYRE, Gilberto. Casa Grande E Senzala. São Paulo: Global Editora, 2006.

GUIMARÃES, Eduardo. Lingua e Cidadania. Campinas: Pontes, 1996.

HAUGEN, Einar. Dialeto, língua, nação. In BAGNO, Marcos. Norma linguística. São Paulo: Edições Loyola, 2001. 


\section{REVISTA DA ABRALIN}

LEAL, Antonio Henriques. O país. nº77 e 78, 27 e 28 de maio de 1871.

LUCCHESI, Dante. O português afro-brasileiro. Salvador: EDUFBA, 2009.

LUCCHESI, Dante. Lingua e sociedade partidas. São Paulo: Editora Contexto, 2015.

MARIANI, Bethania. A colonização linguística. Campinas: Pontes, 2004.

MUNANGA, Kabengele. Rediscutindo a mestiçagem. São Paulo: Autêntica, 2019.

PAGOTTO, Emílio. Norma e Condescendência; Ciência e Pureza. In: Língua e Instrumentos Linguísticos. Campinas: Pontes Editores/HIL, 49-68, 1998.

PETTER, Margarida. Línguas africanas no Brasil. In. África: Revista do Centro de Estudos Africanos. USP, S. Paulo, 27-28: 63-89, 2006/2007

PINTO, Edith Pimentel. O português do Brasil: textos críticos e teóricos, 1 - 1820/1920, fontes para a teoria e a história. Rio de Janeiro: Livros Técnicos e Científicos; São Paulo: Ed. da Universidade de São Paulo. 1978.

POLIAKOV, Léon. O mito ariano: Ensaio sobre as fontes do racismo e dos nacionalismos. São Paulo: Perspectiva, Editora da Universidade de São Paulo, 1974.

RAJAGOPALAN, Kanavillil. Linguagem e xenofobia. Revista estudos linguísticos. XXVI, p. 143-149, 2002.

RODRIGUES, Aryon Dall'Igna. Línguas indígenas: 500 anos de descobertas e perdas. D.E.L.T.A. n.9. v. 1, p. 83-103, 1993.

ROMERO, Sílvio. História da literatura brasileira. Rio de Janeiro: José Olympio, 1949.

SCHWARCZ, Lilia Moritz. O espetáculo das raças: cientistas, instituições e questão racial no Brasil, 1870-1930. São Paulo: Companhia das Letras, 2015.

SCHWARCZ, Lilia Moritz. As marcas do período. In: SCHWARCZ, Lilia Moritz (dir.). História do Brasil Nação: 18082010. Volume 3: A abertura para o mundo, 1889-1930. Rio de Janeiro: Objetiva; Madrid: Fundación MAPFRE, 2012.

SILVEIRA, Allice Toledo Lima da. Os dizeres sobre a mestiçagem nas letras brasileiras entre 1822 e 1930. Tese (Doutorado em Estudos Linguísticos). Universidade Federal de São Carlos - UFSCar, São Carlos (SP), 2018.

TRABANT, Jürgen. Constitution du langage en objet du savoir et traditions linguistiques. Histoire Épistémologie Langage, v. 30, n.1, 2008. Grammaire et mathématiques en Grèce et à Rome. p. 109-126.

VELOSO, Caetano (1993) Letra de Haiti. Música: Gilberto Gil. Letra: Caetano Veloso. Encarte de CD. Tropicália 2, de Caetano e Gil. (Polygram).

VERÍSSIMO, José. Cenas da vida amazônica. Lisboa: Tavares Cardoso, 1886. 